\title{
Evaluation of E-learning Websites Using the Webqual Method and Importance Performance Analysis
}

\author{
Muhammad Labib Jundillah",*, Jatmiko Endro Suseno², and Bayu Surarso ${ }^{3}$ \\ ${ }^{1}$ Magister Program of Information System, School of Postgraduate Studies, Diponegoro University, Semarang - Indonesia \\ ${ }^{2}$ Department of Physics, Faculty of Science and Mathematics, Diponegoro University, Semarang - Indonesia \\ ${ }^{3}$ Department of Mathematics, Faculty of Science and Mathematics, Diponegoro University, Semarang - Indonesia
}

\begin{abstract}
Participant-centered training that uses digital classes leads to changes in the current learning system that focuses on the domain of knowledge. The use of technology in the modern era can be a solution to overcome the issue of expenditure and the quality of educational institutions. The Importance Performance Analysis (IPA) and Webqual methods were chosen in this study because Webqual can translate user opinions in the form of questionnaires and the IPA method is used in managing the results of questionnaire data so that it can produce IPA quadrants. The purpose of this study is to evaluate e-learning websites based on the results of the webqual questionnaire and calculations with the importanceperformance analysis method. The questionnaire was distributed to 95 students with various types of study programs at Stikubank University. The results of the calculation of the IPA method indicate that the average student is satisfied with the quality of the e-learning website at $86.75 \%$. Although there are still some parts that can be improved on e-learning websites such as clear instructions, accurate information, and ease of communication.
\end{abstract}

Keywords: E-learning; user satisfaction; Webqual; Importance Performance Analysis.

\section{Introduction}

E-Learning is one of the alternative methods in the education world. It is expected to cover the weakness that existed or found in conventional education [1]. Elearning is a method of learning that is offered by many universities and educational institutions to support their learning process [2]. E-learning provides better resources than conventional classes in facilitating learning, so it can also overcome limitations in terms of time and space in conventional classrooms [3]. By using e-learning students can learn independently without the need for supervision from conventional learning mechanisms [13]

Applications in learning to use e-learning at universities have encouraged researchers to measure the level of progress in technology-based learning. Usability is important to determine whether something is useful. There are several standards or conceptual models for usability [1]. Researchers have investigated the usefulness of e-learning in the Payame Noor Hamedan University student group, Iran. By dividing chemical students into two groups, on basic chemistry subjects. From the research, it was found that groups of students using e-learning got better grades and higher creativity than those who did not [4]. Besides that, the quality of the website is also an important thing to note. Where research in Malaysia concludes that the quality of a website can have an indirect impact on consumer intentions [5]. The e-learning interface acceptance model is very crucial. It can help the e-learning developer and stakeholder to recognize user needs and requirements in the e-learning system [6].

Importance Performance Analysis (IPA) can be used in measuring management strategies and customer satisfaction levels. This technique can help e-learning providers in diagnosing shortcomings of e-learning websites and setting priorities in the development of elearning websites. The implementation of the Importance Performance Analysis (IPA) method has been used to investigate customer perceptions of smartphone applications against 20 hotel network applications [5].

Therefore the Importance Performance Analysis (IPA) and Webqual Methods are chosen in this paper because Webqual can translate the opinions of users in the form of questionnaires. Then the IPA method is used in managing questionnaire data results so that it can produce IPA quadrants. The IPA quadrants are used as evaluation material from websites e-learning.

\section{Theoretical Background}

\subsection{E-learning}

E-learning refers to various forms of learning that are supported by technology, usually can be characterized as applications of knowledge, information and educational

\footnotetext{
* Corresponding author: labibjundillah@gmail.com
} 
technology to connect people and educational resources, for educational purposes (formal or informal) [7]. Quality in e-learning is divided into two contexts: the first refers to the quality of education in general by using e-learning tools; the second is the quality of e-learning itself which is the subject of improving the quality of elearning [8]. The interface could be very effective in encourage the users' intention and engage them to achieve their goal in the e-learning process [6].

Many companies, individuals to universities that use e-learning as a means to support training and education in improving the quality of education, business strategy, and the quality of human resources. E-learning also has several benefits, namely:

1. E-learning lowers costs

E-learning is one way to save costs for teaching, training, and reducing class infrastructure needs.

2. The message is consistent or adjusted, depending on needs

Everyone gets the same content, so it is given in the same way. But the program can also adjust according to the needs of different study groups or based on the individual.

3. Content can be updated quickly for a certain period The ability to improve e-learning content easily and quickly, and then be able to immediately distribute new information.

4. Learning with unlimited time

E-learning can be accessed by anyone anytime, anywhere. This makes organizational performance global.

5. Scalability

E-learning solutions are very scalable. This program can increase the number of participants from 10 people to 100 or more participants with little effort or additional costs (as long as the infrastructure is still activated) [9].

\subsection{Webqual}

Webqual is a quality measurement technique or method based on the perception of the end user's website. This method is a development of Servqual developed by Parasuraman, which is widely used to measure service quality. Webqual has undergone development in 1998 and has received several changes in the preparation of question items and dimensions. Webqual 4.0 can be divided into 3 research fields, namely: Quality of information from information systems research, Interaction and quality of services from e-commerce, research, and marketing information systems, and usability of human and computer interactions [10].

Barnes and Vidgen divide the questionnaire questions into tables of 3 categories of Webqual 4.0 as shown in Table 1.

Table 1. Webqual Indicator

\begin{tabular}{|l|c|}
\hline Category & Indicator Webqual 4.0 \\
\hline Usability & $-\quad$ Users feel easy to operate the website. \\
& $\begin{array}{c}\text { The interaction between the site and the } \\
\text { user is clear and easy to understand. }\end{array}$ \\
\hline
\end{tabular}

\begin{tabular}{|c|c|}
\hline Category & Indicator Webqual 4.0 \\
\hline & $\begin{array}{l}\text { - Users feel easy to navigate the website. } \\
\text { - Users feel this site is easy to use. } \\
\text { - This website has an attractive } \\
\text { appearance. } \\
\text { - Design according to the type of website. } \\
\text { - The website has clear instructions. }\end{array}$ \\
\hline $\begin{array}{l}\text { Information } \\
\text { Quality }\end{array}$ & $\begin{array}{l}\text { - The website presents accurate } \\
\text { information. } \\
\text { - The website presents reliable } \\
\text { information. } \\
\text { - The website presents information in a } \\
\text { timely manner. } \\
\text { - The website presents relevant } \\
\text { information. } \\
\text { - The website presents information that is } \\
\text { easy to understand. } \\
\text { The website presents information at the } \\
\text { right level. } \\
\text { - The website presents information in the } \\
\text { appropriate format. }\end{array}$ \\
\hline $\begin{array}{l}\text { Service } \\
\text { Interaction }\end{array}$ & $\begin{array}{l}\text { The website has a good reputation. } \\
\text { - Users feel safe to access the website. } \\
\text { - Users feel safe about their personal } \\
\text { information. } \\
\text { - The website provides space for } \\
\text { personalization. } \\
\text { - The website provides space for the } \\
\text { community (lecturers / students). } \\
\text { - The website makes it easy to } \\
\text { communicate with organizations (lecturers, } \\
\text { staff, students, and other stakeholders). }\end{array}$ \\
\hline
\end{tabular}

\subsection{Importance Performance Analysis (IPA)}

It was discovered by Martilla and James that the Importance Performance Analysis method was used in 1977 to analyze the level of customer satisfaction on the organization's products or services. In the long term, Importance Performance Analysis has been used in responding and developing marketing strategies, because this method helps companies understand customer wants and needs [11]. It matters that something is easy but it is not what you want. Satisfaction will drive to the intention of continuance e-learning. A framework for user expectation was introduced describing structures, processes interaction and individual learning, and outcomes of a course [12].

Because user satisfaction is the user's perception, this is related to user expectations, product quality, and service from the organization. So that IPA can measure the level of user satisfaction from the results of user questionnaires based on service components and product attributes, namely: The importance of services and products for users and the level of performance of the organization in providing these services and products.

The IPA technique combines measures of performance and user-perceived interests in a twodimensional plot to facilitate interpretation of data. This plot group attributes into four categories or quadrants to determine the limited allocation of resources. Four quadrants are usually identified as Top priority (Quadrant I), Maintain Achievement (Quadrant II), Low 
Priority (Quadrant III), and Excessive (Quadrant IV) [13].

\begin{tabular}{c|c|c|}
\cline { 2 - 3 } $\begin{array}{c}\text { Importance } \\
\text { (Y) }\end{array}$ & Quadrant I & Quadrant II \\
\cline { 2 - 3 } & Quadrant III & Quadrant III \\
\hline
\end{tabular}

Performance (X)

Fig. 1. Distribution quadrant IPA

Fig.1 shows quadrant Important Performance Analysis which is divided into four quadrants in the IPA diagram as follows:

1. Quadrant I

Quadrant I has a high level of importance but is not in line with user expectations so that performance improvements must be made immediately.

2. Quadrant II

Quadrant II has a high level of importance accompanied by a high level of performance as well and in accordance with user expectations so it must be maintained.

3. Quadrant III

Quadrant III has a low level of importance accompanied by a level of performance that is not too special with a relatively low level of expectation that provides too little benefit for what is felt by the user.

4. Quadrant IV

Quadrant IV has a low level of importance along with a level of performance that is too high so the organization must reallocate these quadrant resources to other quadrants that require improved performance.

In calculating the Important Performance Analysis, this can be done in three steps. The first step is to calculate the level of suitability to determine the level of user satisfaction with existing services. By using the formula as follows [13]:

$$
T k=\frac{x}{Y} * 100 \%
$$

With Tk state the level of suitability of the user, $X$ state the value of the average performance rating, and $\mathrm{Y}$ state the rating value of the average user expectation.

The second step is to determine the position map of important points and performance, making a graph that is limited by two perpendicular intersecting lines to form four intersecting quadrants at the following points [13]:

$$
\begin{aligned}
& \bar{X}=\frac{\sum x i}{n} \\
& \bar{Y}=\frac{\sum v i}{n}
\end{aligned}
$$

Where $\bar{X}$ state the value of average expectations/ interests, $\bar{Y}$ state the average perception/performance score, and $\mathrm{n}$ state the number of respondents.

The final third step is mapping the four quadrants involving all variables that influence the quality of service.

\section{Research Method}

The procedure of this study can be concluded by looking at Fig. 2 below:

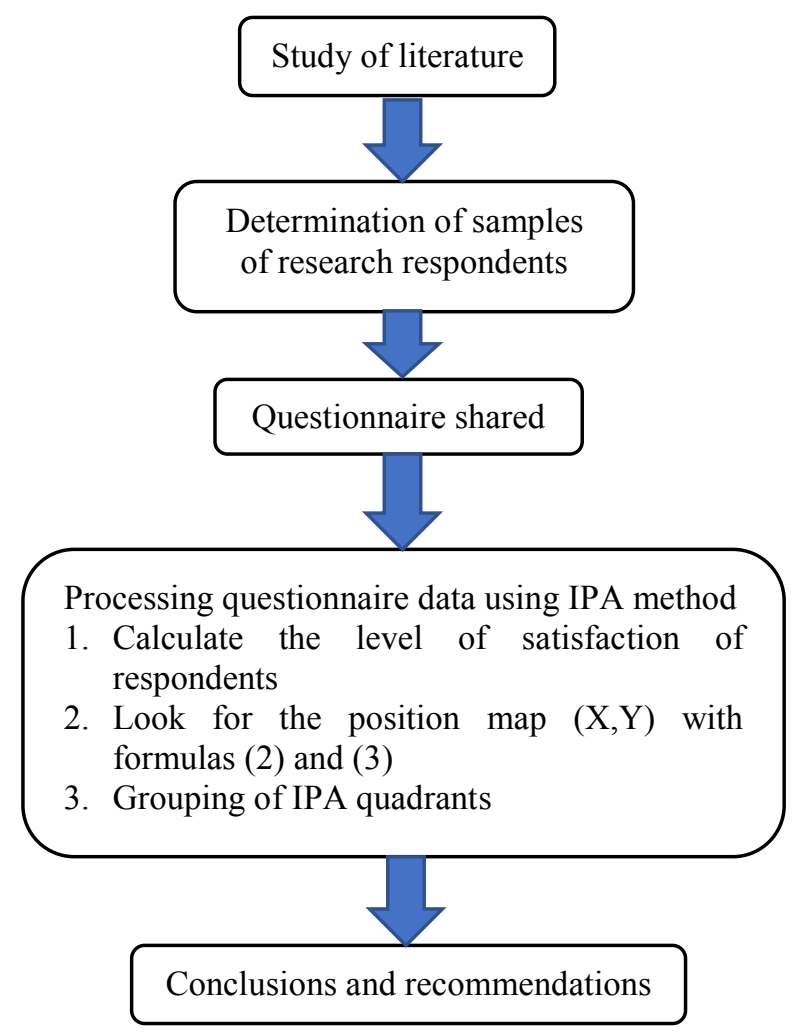

Fig. 2. Research Procedure

Fig. 2 shows the procedure of this study from a literature study to distribute questionnaires to carry out IPA calculations to produce conclusions and recommendations. This study used a sample of 95 random respondents from 1750 e-learning users, who were students at Stikubank University. Using the Webqual questionnaire in Table 1 in the form of 20 statements about the quality of e-learning websites that are divided into important statements and performance statements.

In this study, the Likert scale model is used to interpret the perceptions, opinions, and attitudes of a person or group about social phenomena. Using the Likert scale variable to be measured is explained in the indicator variable. By using a Likert score scale that has 5 categories strongly agree (5), agree (4), quite agree (3), disagree (2), strongly disagree (1) [14].

Data processing begins by evaluating the results of the questionnaire using a Likert scale. The next step is done by the scientific calculation method to determine the level of student satisfaction using the formula (1), then determine the map of the quadrant position using formula (2) and (3). Processing the results of this study using Microsoft Excel with SPSS (Statistical Product and Service Solution). 


\section{Result and Discussion}

This paper provides results in the form of an e-learning website evaluation system using the Webqual and Importance Performance Analysis (IPA) methods. This system contains the results of a questionnaire from Stikubank University Semarang students from various study programs.

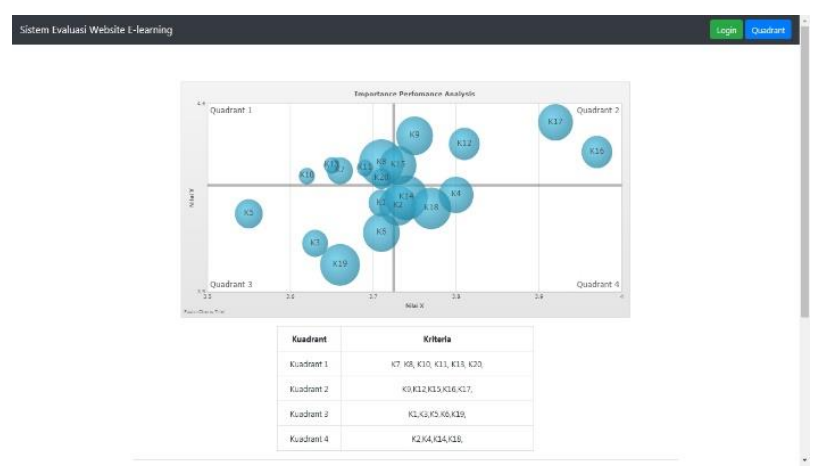

Fig. 3. E-learning Website Evaluation System

Fig. 3 shows the results of the system that has been made, which shows a graph of the IPA quadrant. By suggesting the recommendations below as an improvement based on the IPA quadrant graph.

The calculation results use the IPA method which is divided into three steps. The first step is to calculate the suitability of respondents using formula (1). Table of levels of user satisfaction can be seen in Table 2 .

Table 2. User satisfaction level

\begin{tabular}{|c|c|c|c|}
\hline Criteria & $\begin{array}{c}\text { Performance } \\
(\mathrm{X})\end{array}$ & $\begin{array}{c}\text { Importance } \\
(\mathrm{Y})\end{array}$ & $\begin{array}{c}\text { Satisfaction } \\
\text { Level (\%) }\end{array}$ \\
\hline K1 & 352 & 402 & 88 \\
\hline K2 & 354 & 401 & 88 \\
\hline K3 & 345 & 388 & 89 \\
\hline K4 & 361 & 405 & 89 \\
\hline K5 & 337 & 398 & 85 \\
\hline K6 & 352 & 391 & 90 \\
\hline K7 & 348 & 413 & 84 \\
\hline K8 & 352 & 416 & 85 \\
\hline K9 & 356 & 426 & 84 \\
\hline K10 & 344 & 411 & 84 \\
\hline K11 & 351 & 414 & 85 \\
\hline K12 & 362 & 423 & 86 \\
\hline K13 & 347 & 415 & 84 \\
\hline K14 & 355 & 404 & 88 \\
\hline K15 & 354 & 415 & 85 \\
\hline K16 & 377 & 420 & 90 \\
\hline K17 & 372 & 430 & 87 \\
\hline K18 & 358 & 400 & 90 \\
\hline K19 & 348 & 380 & 92 \\
\hline K20 & 352 & 410 & 86 \\
\hline & Average & & 86,75 \\
\hline
\end{tabular}

By looking at the results of calculations in Table 2 about the level of suitability of users who also describe the level of satisfaction of users of the Stikubank University e-learning website. Based on these results, the K19 category gets the highest score with $92 \%$, which means that e-learning websites have provided excellent community space for students. Different from the criteria $\mathrm{K} 7, \mathrm{~K} 9, \mathrm{~K} 10$, and K13 which have the lowest values of all criteria, which indicates that website instructions, reliable information, timely information, and presentation of information at the right level are less satisfactory. However, the average score of user's suitability is $86.75 \%$ so it can be said that the e-learning website from Stikubank University is satisfying.

In the second step, the process of mapping the position of each criterion is done by looking for the averages in positions $\mathrm{X}$ and $\mathrm{Y}$ using formulas (2) and (3) so that they can form four IPA quadrants. The points from each coordinate can be seen in Table 3 .

Table 3. The IPA coordinates

\begin{tabular}{|c|c|c|c|}
\hline Criteria & $\begin{array}{c}\text { Average } \\
\text { Performance } \\
(\mathrm{X})\end{array}$ & $\begin{array}{c}\text { Average } \\
\text { Importance } \\
(\mathrm{Y})\end{array}$ & Quadrant \\
\hline K1 & 3.71 & 4.23 & Quadrant III \\
\hline K2 & 3.73 & 4.22 & Quadrant IV \\
\hline K3 & 3.63 & 4.08 & Quadrant III \\
\hline K4 & 3.80 & 4.26 & Quadrant IV \\
\hline K5 & 3.55 & 4.19 & Quadrant III \\
\hline K6 & 3.71 & 4.12 & Quadrant III \\
\hline K7 & 3.66 & 4.35 & Quadrant I \\
\hline K8 & 3.71 & 4.38 & Quadrant I \\
\hline K9 & 3.75 & 4.48 & Quadrant II \\
\hline K10 & 3.62 & 4.33 & Quadrant I \\
\hline K11 & 3.69 & 4.36 & Quadrant I \\
\hline K12 & 3.81 & 4.45 & Quadrant II \\
\hline K13 & 3.65 & 4.37 & Quadrant I \\
\hline K14 & 3.74 & 4.25 & Quadrant IV \\
\hline K15 & 3.73 & 4.37 & Quadrant II \\
\hline K16 & 3.97 & 4.42 & Quadrant II \\
\hline K17 & 3.92 & 4.53 & Quadrant II \\
\hline K18 & 3.77 & 4.21 & Quadrant IV \\
\hline K19 & 3.66 & 4.00 & Quadrant III \\
\hline K20 & 3.71 & 4.32 & Quadrant I \\
\hline
\end{tabular}

As with coordinates that can be seen in Table 3, the process becomes a graph of the IPA quadrant at the next stage. The final step is to do an analysis by mapping four science quadrants involving all the criteria that have an effect based on the results of the questionnaire that has been given. Four IPA quadrants can be displayed in Fig. 4. 


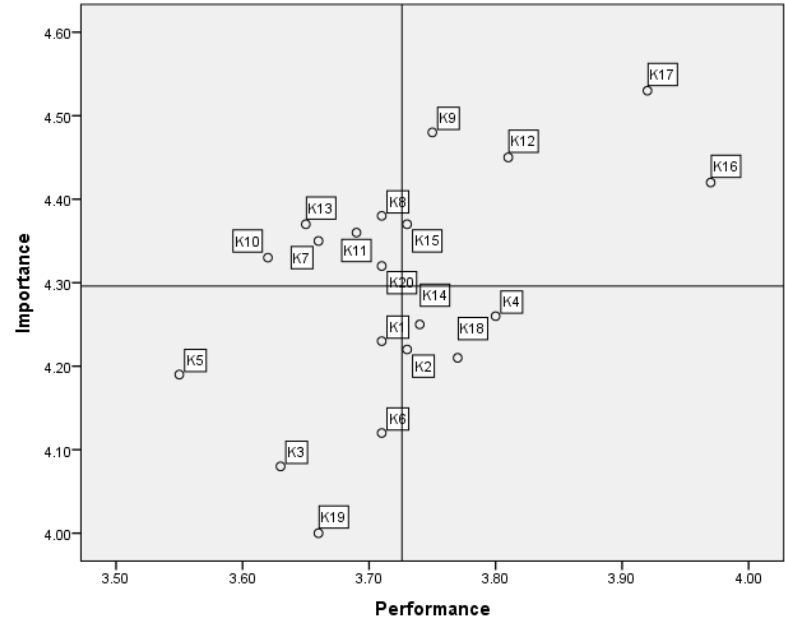

Fig. 4. Quadrant graph of IPA

Based on the graph results of four IPA quadrants in Fig. 4 then it can be concluded that the criteria that enter each quadrant, namely:

1. Quadrant I: Quadrant I has a relatively high level of importance but has inadequate performance so it needs to be improved to improve the performance of e-learning websites. The criteria included in this quadrant are K7 (Having clear instructions), K8 (Presenting accurate information), K10 (Presenting information on time), K11 (Presenting relevant information), K13 (Presenting information at the right level), and K20 (Provides convenience to communicate with organizations).

2. Quadrant II: Quadrant II as a relatively high level of importance with a high level of performance that is also relevant so that it is in accordance with the wishes of the user and must be maintained. The criteria included in this quadrant are K9 (Presenting reliable information), K12 (Presenting easy-tounderstand information), K15 (Having a good reputation), K16 (Feeling safe accessing websites), and K17 (Feeling safe about personal information).

3. Quadrant III: Quadrant III has a relatively low level of importance with a relatively low level of performance so there is no need to make improvements because it is not the user's top priority. The criteria included in this quadrant are K1 (Feel easy to operate the website), K3 (Feel easy to navigate on the website), K5 (Have an attractive appearance), K6 (According to the type of website), and K19 (Give space for the community).

4. Quadrant IV: Quadrant IV has a relatively low level of importance but has a relatively high level of performance so the university needs to transfer these excess performance resources to other quadrants that require improved performance. The criteria included in this quadrant are K2 (Interactions between users and websites are clear and easy to understand), K4 (Web sites that feel easy to use), K14 (Presenting information in the appropriate format), and K18 (Providing space for personalization).

\section{Conclusion}

Based on the results of research and discussion that the evaluation system of e-learning websites at Stikubank University uses the Webqual method and the importance of performance analysis can show the results of quality evaluations from the Stikubank University e-learning website. Using the 95 results of the student questionnaire about the quality of the university e-learning website using 20 Webqual criteria statements. Furthermore, the data is processed using the IPA method steps. The results of the level of student satisfaction with e-learning websites ranged from $84 \%$ to $92 \%$ with an average of $86.75 \%$, which was included in the satisfying category. While the criteria that need to be improved are K7 (Having clear instructions), K8 (Promoting accurate information), K10 (Presenting information in a timely manner), K11 (Presenting relevant information), K13 (Presenting information at the right level) and K20 (makes it easy to communicate with organizations).

\section{References}

1. Ramadiani, et.al. Jurnal Sistem Informasi 9, 6 (2013)

2. Ramadiani, A. Rodziah, A. Rusli, S.M. Hasan, C. Noeraini, IOP Conf. Series: Materials Science and Engineering 105, (2016)

3. T.H. Wang, Computer and Education 73, 189 (2014)

4. M. Zare, R. Sarikhani, M. Salari, V. Mansouri, Journal of Technology Education and Training 8, 25 (2016)

5. J. Hasanov, H. Khalid, Procedia Computer Science 72, 382 (2015)

6. Ramadiani, R. Atan, A. Rusli, IEEE 2nd International Conference on Science in Information Technology ICSITech, 158 (2016)

7. M. Chen, H. Murphy, S. Knecht, Journal of Hospitality and Tourism Management 29, 69 (2016)

8. U.D. Ehler, J.R. Hilera, Journal of Computer Assisted Learning 28, 1 (2012)

9. V. Teodora, U. Mioara, N. Magdalena, Journal of Knowledge Management, Economics and Information Technology 3, 1 (2013)

10. Rosenberg, M. Jeffrey, E-learning: Strategis for Delivering knowledge in the Digital Age, Mc GrawHill Profesional (2001)

11. J.S. Barnes, R. Vidgen, Journal of Electronic Commerce Research 3, 114 (2003)

12. Ramadiani, Azainil, U. Haryaka, F. Agus, A.H. Kridalaksana, Procedia Computer Science 116, 373 (2017)

13. J.A. Martila, J. James, Journal of Marketing 41, 77 (1977)

14. Sugiyono, Research Methods in Business, Alfabeta, Bandung (2013) 